8. Levine S, Nguyen T, Taylor $\mathrm{N}$ et al. Rapid disuse atrophy of diaphragm fibers in mechanically ventilated humans. N Engl J Med 2008; 358: 1327-35.

9. Martin AD, Smith BK, Davenport PD et al. Inspiratory muscle strength training improves weaning outcome in failure to wean patients: a randomized trial. Crit Care 2011; 15: R84.

10. Sathasivam S. Current and emerging treatments for the management of myasthenia gravis. Ther
Clin Risk Manag 2011: 7: 313-23

11. Ibrahim H, Dimachkie MM, Shaibani A. A review: the use of rituximab in neuromuscular diseases. $J$ Clin Neuromuscul Dis 2010; 12: $91-102$

12. Lindberg C, Bokarewa M. Rituximab for severe myasthenia gravis - experience from five patients. Acta Neurol Scand 2010; 122: 225-8

13. Lau AY, Chan AY, Mok VC. Refractory bulbar and respiratory dysfunction in a young Chinese woman with seronegative, muscle-specific tyrosine kinase antibody-positive myasthenia gravis: response to cyclophosphamide and rituximab treatment. Hong Kong Med J 2011; 17: 77-9.

Mottatt 17.11. 2011, første revisjon innsendt 24.2 2012, godkjent 21.6. 2012. Medisinsk redaktør Petter Gjersvik.

\title{
Kommentar
}

\section{Vanskelig behandling - mange valg}

Myasthenia gravis er en autoimmun sykdom som rammer den nevromuskulære synapse. Sykdommen forårsakes i de fleste tilfellene av antistoff mot nikotinerg acetylkolinreseptor (AChR) på den postsynapstiske muskulære del av synapsen. I sjeldne tilfeller er sykdommen forårsaket av antistoff mot muskelspesifikk tyrosinkinase (MuSK) eller mot lipoproteinrelatert protein 4 (LRP4).

Myasthenia gravis er en relativt sjelden sykdom, med en prevalens på ca. 150 tilfeller og en insidens på rundt 10-15 nye tilfeller per million innbyggere per år. Sykdommen manifesterer seg med okulære symptomer som diplopi og ptose, bulbære symptomer som dysartri og dysfagi og generaliserte symptomer med pareser i nakkemuskulatur og proksimal ekstremitetsmuskulatur. Typisk er fluktuerende symptomer med bedring etter hvile.

Behandlingen av myasthenia gravis er symptomatisk ved å hemme ACh-esterase i synapsen med pyridostigmin og immunologisk med kortikosteroider eller annen immunsuppresjon (1). Tymektomi er aktuelt hos pasienter med tymom (ca. 10-15\%) og hos dem med generalisert myasthenia gravis. Vedlikeholdsbehandling skjer som regel med pyridostigmin og lavdose prednisolon, eventuelt med azatioprin som steroidsparende medikament. En rekke andre immunsuppressive medikamenter kan forsøkes, slik som mykofenolatmofetil, rituximab, metotreksat eller ciklosporin $(1,2)$.

I dette tilfellet beskrives en pasient med kjent myasthenia gravis og myastenisk krise. En rekke forhold kan forverre myasthenia gravis, slik som ulike medikamenter som påvirker den nevromuskulære synapse - og ikke minst infeksjoner, som var tilfellet her. Behandling av myastenisk krise er intravenøst immunglobulin (IvIg) eller plasmautskiftning. Disse behandlingene gir rask bedring, og studier viser at de har likeverdig effekt. Høydose kortikosteroider kan også bedre myastenisk krise hvis de forutgående behandlinger ikke har hatt tilstrekkelig effekt. Dette ble gitt ut i behandlingsforløpet hos aktuelle pasient i tillegg til antibiotika for pneumoni. Det er også vist at rituximab kan bedre forløpet, og dette medikamentet bør forsøkes hvis ikke intravenøst IgG eller kortikosteroider har gitt resultater $(2,3)$. Pasienten ble markant bedre etter sistnevnte behandling.

Denne sykehistorien illustrerer viktige poenger. Myastenisk krise kan være vanskelig å behandle. Immunsuppressiv behandling må ofte gis på tross av pågående infeksjon.
Intravenøst IgG, kortikosteroider og rituximab er aktuelle medikamenter i angitt rekkefølge ved myastenisk krise.

\section{Christian Vedeler}

christian.vedeler@helse-bergen.no

Christian Vedeler (f. 1958) er overlege ved Nevrologisk avdeling, Haukeland universitetssykehus, og professor i nevrologi ved Universitetet i Bergen.

Forfatter har fylt ut ICMJE-skjemaet og oppgir ingen interessekonflikter.

\section{Litteratur}

1. Skeie GO, Apostolski S, Evoli A et al. Guidelines for treatment of autoimmune neuromuscular transmission disorders. Eur J Neurol 2010; 17: 893-902.

2. Díaz-Manera J, Rojas García R, Illa I. Treatment strategies for myasthenia gravis: an update. Expert Opin Pharmacother 2012; 13: 1873-83.

3. Gilhus NE, Owe JF, Hoff JM et al. Myasthenia gravis: a review of available treatment approaches. Autoimmune Dis 2011. E-publisert 5.10.2011.

Manuskriptet ble mottatt 14.8. 2012 og godkjent 29.8. 2012. Medisinsk redaktør Petter Gjersvik. 